\title{
Studying effect of intellectual capital on insurance demand increase (Case study: Asia insurance company)
}

\author{
Ali Naghi Amiri ${ }^{\mathrm{a}}$, Ali HamidiZadeh ${ }^{\mathrm{b}}$, Elham Sheikholeslamic \\ Farabi Campus, University of Tehran, Iran \\ E-mail address: \\ Anamiri@ut.ac.ir, Hamidizadeh@ut.ac.ir, sheikholeslami.e@gmail.com
}

Keywords: intellectual capital, demand, insurance, insurance company

\begin{abstract}
Difference in the companies' performance is resulted by the fact that successful organizations have strategic resources (physical, human, and structural) that their Competitors doesn't have. So, difference in these resources have prominent role to create benefit for companies. The main purpose of the present study is to study intellectual capital effect on insurance demand increase in Asia insurance company and tries to study the effect of three dimensions of intellectual capital (human, structural and customer) on insurance demand increase in Asia insurance company. Research method in terms of the goal is applicable, and in terms of the study method is descriptive and is of survey branch. Population of the study consists of all officers of central organizations of Asia insurance company in Tehran. The sample size is 132 officers of the central office of Asia Insurance Company. Data collected by questionnaire and analyzed by One Sample T-Test. The results indicate that intellectual capital and it's dimensions, have effect on insurance demand increase in Asia insurance company.
\end{abstract}

\section{INTRODUCTION}

Human is always looking for his welfare and convenience and since there are a lot dangers in human life, they are always looking for finding the ways to combat these risks or, at least, to mitigate their consequences. One solution is to use insurance entities shaped to mitigate losses from such risks and can cover apart of human needs. Overall, activities in insurance industry lead into human welfare and convenience and play a vital role in improving people's future life [1]. To this end, the manager and heads of companies in insurance industry plan to attract current and new insured for their future activities[16] so that it becomes possible to improve demand for insurance by all people and one can retain the health, stability and security of the society one the one hand [9] and to promote financial profit and performance in the industry on the other hand.

In Dehkhoda Encyclopedia, demand means request and inquiry. In economy, it means the tendency and request and ability of someone to receive goods or services (Wikipedia, 2014). On the other hand, the product of insurance companies is convenience against perils [18]. In fact, insurance demand is assurance demand [26]. More satisfaction of insured by insurers' services would lead into mote attraction and more demand for coverage [2].

Different factors impact on insurance demand increase in society and achieving it needs facilities inside insurance companies.

Since the expansion and development of all organizational activities including service or manufacturing owes the existence of demands in the market for goods and services of the relevant organization, the importance of customers in survival or destruction on an organization is revealed more. For service providers and manufacturers, there is no option rather than customer satisfaction [15].

"On the other hand, a rapid and important change to which businesses are facing in today knowledge - oriented economy and has transformed economic activities of organizations is that in recent past decades, there were radical changes in the structure of organizational resources. The main resources of companies included not only tangible but also intangible resources that are rare, invaluable non-replaceable and endless" [19]. 
Under such circumstances, intangible assets and intellectual capitals are seen as the main profitability factors for companies. Overall, the importance of intellectual capital in generating values at knowledge - oriented economy cannot be ignored (ibid). "Intellectual capital creates a new source and base by which the organization can compete" [11]. "Intellectual capital is collective mental ability or a set of key knowledge" (Qelichkhani, 2013). "Therefore, intellectual capital can play a vital role in improving the value and financial improvement of companies [19].

According to conducted researches by different authors in previous years, intellectual capital and its components have a positive impact on organizational performance including insurance industry and generate added - value and, consequently, increase in organizational product demands. Accordingly, an organization should enforce and grow intellectual capital and its aspects as a priority if it wants that its products are highly demanded by customers. Therefore, researcher is facing with this question: "do intellectual capital and its components impact on insurance demand increase by individuals in the society?"

\section{RESEARCH THEORETICAL LITERATURE}

\section{Intellectual capital}

"In today competitive environment in which the capabilities of companies are too important in distinguishing their competitive performance through applying and exploiting their intangible capital, the importance of other resources is decreased" [23]. As the result of intangible capitals, productive intellectual capital has greater economic value in short, middle and long terms (Qelichkhani, 2013). According to Stewart, intellectual capital is an important intellectual factor which includes knowledge, information, intellectual assets and experiences which can be used to generate wealth [11].

Therefore, the main hypothesis of the research is:

Intellectual capital impacts on insurance demand increase (in Asia Insurance Company).

In 1998 and following to its past theories, Bontis announced that intellectual capital includes customer capital, structura capital and human capital [22]. Stewart (1997) also provided its categories on intellectual capital as human capital, structural capital and relational capital (Molaei, 2008).

Human capital means employees' knowledge, skills and capabilities as well as the values and the culture of the company. A company cannot own human capital (Bukh et al, 2005). Human capital includes individuals' capacities and capabilities as the resources of innovation in organization (Lopez Saez et al, 2010). Therefore, human capital is the initial resource of innovation and organizational competition (Bahraum \& Pitt, 2009).

Thus, the first sub-hypothesis is:

Human capital impacts on insurance demand increase (in Asia Insurance Company).

Relational capital refers to an organization's potentiality and ability in terms of intangible assets outside that organization. These intangible assets include the knowledge in relations between organization and its customers, suppliers, government and commercial associations [22]. Stewart (1997) asserts that customer capital is market information used in attracting and keeping customers [8].

Thus, the second sub-hypothesis is:

Customer (relational) capital impacts on insurance demand increase (in Asia Insurance Company).

Structural capital includes infrastructural assets such as technologies, processes and procedures as well as intellectual assets like know - how, trademarks and patents [12]. According to Chen et al, structural capital refers to the mechanism and structure of a commercial unit which can support employees to improve their intellectual performance so that the organization can improve its performance [5].

Thus, the third sub-hypothesis is:

Structural capital impacts on insurance demand increase (in Asia Insurance Company). 


\section{Demand concept}

In Dehkhoda Encyclopedia, demand means request and inquiry. In economy, it means the tendency and request and ability of someone to receive goods or services (Wikipedia, 2014). Demand curve is a geometrical location of points which shows how much someone is ready to pay in order to achieve a product or service. Demand curve slope is negative, namely, increase in premium decreases demand. In addition to premium, there are many other factors which impact on individuals' demand including alternative goods, consumers' tastes, future inflationary expectations and consumers' income (Wikipedia, 2014).

\section{Insurance demand increase}

Overall, human is exposed by various risks which can be divided into life and financial ones. Financial risks include fire, flood and earthquake while life risks include deaths due to accidents or organ disability which yields into losing or mitigating personal financial and economic incomes.

In this vein and far from spiritual life and religious beliefs, the role of insurance companies is undeniable in mitigating pressures and anxieties in human life. By their attendance, these companies can create proper guidelines for people's convenience through proper insurance coverage [3].

Therefore, insurance leads into insured's convenience, trust and confidence [14]. Thus, insurance demand is confidence demand [26]. In other word, insurance means to guarantee, purvey, trust or confidence [10]. On the other hand, "infrastructural concept of marketing is to identify the needs and to satisfy customers which lead into customers' retain. It indicates that better quality and servicing to customers by organization would lead into their more satisfaction (Khosrawi, 2009). More insured's satisfaction by insurance companies' services would yield into more attraction of coverage and more demand" [2].

Such factors as risk taking [26], income level, population size, life expectancy and educational level relate directly to insurance demand and such variables as premium, competitive profit, age increase, unemployment, religion, social security and supervising/legal environment (Outreville, 2013) are related to insurance demand reversely.

\section{Background}

According to thinkers, intellectual capital is one of the most important competitive advantages of organizations. There are many evidences which say intellectual capital has a positive impact on organizational performance. Below examples indicate that intellectual capital has a positive impact on organizational performance and innovation and profitability.

In 2012, Mohammad Alipour studied the impact by intellectual capital on the performance of Iranian insurance companies and concluded that intellectual capital and its aspects have a positive and significant relationship to profitability. In their study titled "intellectual capital and financial performance of Indian banks", Santana Kumargosh and Amithawa Mondall (2012) concluded that banks' intellectual capital is too vital for their competitive advantage. In 2008, Takuyuki Sumita (2008) in his study titled "the management of intellectual assets for innovation" concluded that as an innovation driving force, promoting intellectual assets management is too important in company's policy and working agenda.

\section{Research conceptual models}

According to relevant literature and elites' opinions, the impact by intellectual capital on insurance demand increase is shown through below model. As seen in the figure, it has one independent variable namely "intellectual capital" while its aspects include "human capital", "structural capital", and "customer (relational) capital". Likewise, research dependent variables in "insurance demand increase". 


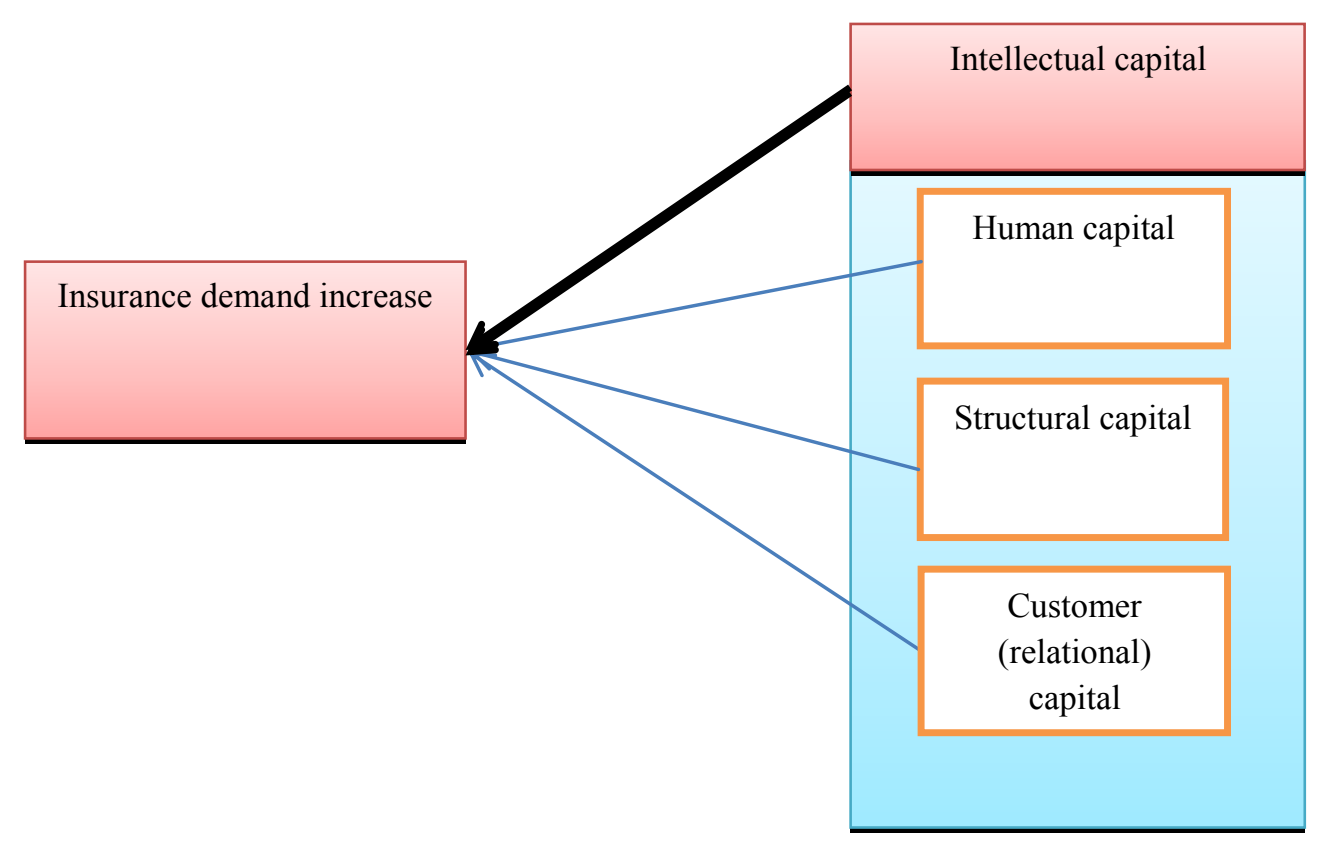

Figure 1: Research conceptual model

\section{METHODOLOGY}

Since the aim of current study is to investigate the impact of intellectual capital on insurance demand increase, it is an applied study in terms of purpose while it is a descriptive survey in terms of data collection and analysis method. In present study, research population includes all personnel (270) of Asia Insurance Company's head office in Tehran Province of whom 159 were selected as sample by Morgan Table. In this study, Bontis' standard intellectual capital questionnaire is used that its validity and reliability are confirmed in Canada and Malaysia. It has items on the impact of each aspect of intellectual capital on insurance demand increase and designed in Likert five - point scale. By using Cronbach's alpha value, reliability is computed as 0.856 for total questionable which is admirable while its validity was supported by relevant elites and instructors. Relevant information is analyzed by using descriptive and deductive statistical methods. The results form descriptive statistics indicate that average age of employees in Asia Insurance Company in $31-31$ years - old while their average education is bachelor and their job service is $6-10$ years. Half of the sample was male. In deductive analysis, $t$ - test was used for a single sample (to study the impact of intellectual capital and its aspects on insurance demand increase).

\section{Research findings}

The results from hypotheses tests include:

Main hypothesis:

Intellectual capital impacts on insurance demand increase (in Asia Insurance Company).

Sub-hypotheses:

(1) Human capital impacts on insurance demand increase.

(2) Structural capital impacts on insurance demand increase.

(3) Customer (relational) capital impacts on insurance demand increase. 
Table 1: $t$ - test to measure the impact of intellectual capital and its aspects on insurance demand increase

\begin{tabular}{|c|c|c|c|c|c|c|c|c|c|}
\hline \multirow{3}{*}{ Deduction } & \multirow{2}{*}{\multicolumn{2}{|c|}{$\begin{array}{r}\mu 4> \\
\text { (Sig) } \\
\end{array}$}} & \multirow{3}{*}{ Average } & \multirow{3}{*}{ Deduction } & \multirow{2}{*}{\multicolumn{2}{|c|}{$\begin{array}{r}\mu 3> \\
\text { (Sig) }\end{array}$}} & \multirow{3}{*}{ Average } & \multirow{3}{*}{ QTY } & \multirow{3}{*}{$\begin{array}{l}\text { Asia Insurance } \\
\text { Company }\end{array}$} \\
\hline & & & & & & & & & \\
\hline & $\begin{array}{l}\text { High } \\
\text { level }\end{array}$ & Low level & & & $\begin{array}{l}\text { High } \\
\text { level }\end{array}$ & $\begin{array}{l}\text { Low } \\
\text { level }\end{array}$ & & & \\
\hline \multirow{3}{*}{$\begin{array}{l}\text { Higher than } 4 \\
\qquad(<4 \mu 5<)\end{array}$} & & $\mu 4>$ & \multirow{3}{*}{4.18} & \multirow{3}{*}{$\begin{array}{l}\text { Higher than } \\
\text { average } \\
\\
(<3 \mu)\end{array}$} & & $\mu 3>$ & \multirow{3}{*}{4.18} & \multirow{3}{*}{159} & \multirow{3}{*}{$\begin{array}{r}\text { Intellectual } \\
\text { capital }\end{array}$} \\
\hline & & 0.000 & & & & 0.000 & & & \\
\hline & 0.11 & 0.22 & & & 1.11 & 1.22 & & & \\
\hline \multirow{3}{*}{$\begin{array}{l}\text { Higher than } 4 \\
\qquad(<4 \mu 5<)\end{array}$} & & $\mu 4>$ & \multirow{3}{*}{4.2} & \multirow{3}{*}{$\begin{array}{l}\text { Higher than } \\
\text { average } \\
\qquad(<3 \mu)\end{array}$} & & $\mu 3>$ & \multirow{3}{*}{4.2} & \multirow{3}{*}{159} & \multirow{3}{*}{ Human capital } \\
\hline & & 0.000 & & & & 0.000 & & & \\
\hline & 0.13 & 0.27 & & & 1.13 & 1.27 & & & \\
\hline \multirow{2}{*}{$\begin{array}{r}4 \\
(\mu=4)\end{array}$} & & $\mu 4>$ & \multirow[b]{2}{*}{4.06} & \multirow{2}{*}{$\begin{array}{l}\text { Higher than } \\
\text { average } \\
(<3 \mu)\end{array}$} & & $\mu 3>$ & \multirow[b]{2}{*}{4.06} & \multirow[b]{2}{*}{159} & \multirow{2}{*}{$\begin{array}{r}\text { Structural } \\
\text { capital }\end{array}$} \\
\hline & & 0.08 & & & & 0.000 & & & \\
\hline \multirow{4}{*}{$\begin{array}{l}\text { Higher than } 4 \\
\qquad(<4 \mu 5<)\end{array}$} & & $4>$ & \multirow{4}{*}{4.24} & \multirow{4}{*}{$\begin{array}{l}\text { Higher than } \\
\text { average } \\
\qquad(<3 \mu)\end{array}$} & & $13>$ & \multirow{4}{*}{4.24} & \multirow{4}{*}{159} & \multirow{4}{*}{$\begin{array}{r}\text { Customer } \\
\text { (relational) } \\
\text { capital }\end{array}$} \\
\hline & & & & & & & & & \\
\hline & & 0.000 & & & & 0.000 & & & \\
\hline & 0.17 & 0.29 & & & 1.17 & 1.29 & & & \\
\hline
\end{tabular}

According to table 1, one can say that the impact by intellectual capital and its aspects (human, structural and customer capitals) on insurance demand increase (in terms of Asia Company's employees) is greater than average which shows high impact by intellectual capital and its aspects on insurance demand increase. Therefore, main and sub-hypotheses are confirmed. It means that intellectual capital and its aspects impact on insurance demand increase.

\section{CONCLUSION}

In recent years, competitive advantages of strategies are highly discussed. In fact, companies have resources for their strong financial performance and vital competitive advantage. The firs resource is tangible assets such as properties, machines and physical technologies which has alternatives and can be easily traded in free markets. The second one is intangible assets that are valuable, without any alternative and strategic capable to create competitive advantage and superior financial performance [17]. Intellectual capital is an intangible asset in an organization. Edvinson and Sullivan (1996) defined intellectual capital as a knowledge which can be transformed to value and introduced it as practical experiences, organizational technology, customer relations and professional skills to achieve competitive advantages [7]. The aim of the research is to study the impact by intellectual capital on insurance demand increase in Asia Insurance Company. Research population includes all personnel (270) of Asia Insurance Company's head office in Tehran Province of whom 159 were selected as sample by Morgan Table. All data were collected by a $25-$ item questionnaire devised by researcher and analyzed by single $t-$ test. The results from testing the researches indicate that intellectual capital and its aspects impact on insurance demand increase in Asia Insurance Company.

\section{Recommendations}

A very important and proper initiative in Asia Insurance Company was to foster intellectual capital and its aspects (human, structural and customer capitals) by its mangers. Therefore, one can provide three recommendations to improve intellectual capital in Asia Insurance Company as below:

(1) Below recommendations are provided to improve human capital aspect:

Undoubtedly, an important factor which has the highest impact on insurance industry competitiveadvantage in recent years is high skills, specialty and experience of employees in selling insurance coverage. Aggregating such factors along with new service provisions would yield into more qualitative products and, as a result, higher competitive advantage. Thus, one can attract more customers. 
(2) Below recommendations are provided to improve structural capital aspect:

It is recommended that managers of the company pay more attention to such factors as using structural capitals like IT facilities; regulations, enforcing the strategies; evaluating HR productivity; deregulation; and using recommendations system inside the organization to receive the opinions of employees and also customers outside the company. These factors make it possible for companies to achieve higher competitive advantage and attract more customers.

(3) Below recommendations are provided to improve customer capital aspect:

Managers are recommended to pay more attention to such factors as grooming staff so that they can provide customers with full services; identifying customers' needs; enhancing customer orientation among all organizational members; and on-time responding to customers' expectations and complaints. These factors make it possible for companies to achieve higher competitive advantage and attract more customers.

\section{References}

[1] Baratpour, Mostafa (2011), "analyzing the role of human capital on life insurance (case study: Tehran), M. S. dissertation, Azad Islamic University, Tehran

[2] Pezeshk Falah, Zahra (2001), "studying main affecting factors on vehicle body insurance and estimating a proper pattern, Insurance Industry Quarterly, vol. 3, pp. 133 - 158

[3] Jalali Lavasani, Ehsan (2005), "studying the impact of macroeconomic variables on the demand of persons' insurance”, Insurance Industry Quarterly, vol. 2, pp. 117 - 158

[4] Sumita, Takayuki. (2008), "Intellectual assets based management for innovation Lessons from experiences in Japan, Journal of Intellectual Capital, 9(2), pp. 206-227.

[5] Chupani, Heydar; Zare Khalili, Mojtaba; Ghasemi, Aghil; Gholamzadeh, Hujjat (2012), "studying the relationship between intellectual capital and organizational innovation (case study: Towseh Insurance Company)", Creativity in Human Sciences, vol. 1, pp. 27 - 58

[6] Khosravi, Amir (2009), "studying affecting factors of service quality on satisfaction and loyalty", Azad Islamic University, Irak Dehkhoda Encyslopedia, www.vajehyab.com

[7] Fetres Mohammad Hassan \& Beigi, Turaj (2010), “comparative study of intellectual capital impacts on organizational performance of Iranian banking industry in both public and private sectors, case study: banks in Tehran”, Executive Management Research letter, vol. 1, pp. 101 125

[8] Qelichli, Behruz (2013), knowledge management: the process of creating, sharing and applying intellectual capital in businesses, SAMT, Tehran, p. 252

[9] Kazemi, Mustafa, (2013), insurance penetration ratio through compulsory insurances, www.bina.ir

[10] Karimi, Ayat (2011), insurance overviews, Insurance Research Center

[11] Mojtahedzadeh, Vida (2010),, the relationship between intellectual capital (human, customer, structural) and insurance industry performance (in terms of managers), Auditing and Accounting Studies, vol. 17, pp. $109-119$

[12] Moshabaki, Asghar \& Qelichli, Behruz (2007), “comparative advantage: clarifying the role of intellectual capital and social capital”, Human Science Instructor Quarterly, vol. 3, pp. 233 260

[13] Malaei, Fatemeh (2008), “intellectual capital performance appraisal by using BSC model”, dissertation, Management School, University of Tehran

[14]Morely, Philip (2012), insurance marketing, translated by Vazifehdoost, Hussein \& Hassannejad Kashani, Behzad, Shahr Ashoob ublications, Tehran, p. 226 
[15] Moven, John \& Minor, Michel (2009), consumer's behavior, translated by Heydarzadeh, Kambiz, Azad Islamic University Press, Qazvin p. 553

[16] Mahdavi, Ghadir \& Seiflu, Sajjad (2011), "the guidelines to develop insurance in money and capital market", pp. $1-26$

[17]Namazi, Mohammad \& Ebrahimi, Shahla (2001), "studying empirical role of human capital components in evaluating financial operation of Tehran Stock Exchange listed companies, Accounting Progress Journal, University of shiraz, vol. 3, pp. $163-197$

[18] Norouzi, Feizollah \& Molazadeh, Manli (2013), "studying insured's satisfaction from life insurance and its affecting factors", Binesh, vol. 58, pp. 1 - 18 Wikipedia (2014), demand, www.wikipedia.org

[19]Alipour, Mohammad, (2012). "The effect of intellectual capital on firm performance: An investigation of Iran insurance companies", MEASURING BUSINESS EXCELLENCE, 16(1),pp. 53-66

[20]Baharum, M. R; Pitt, M. (2009), "Determining a conceptual framework for green FM intellectual capital", Journal of Facilities Management, 7)4(; pp. 267-282

[21]Bukh, Per Nikolaj; Christensen, Kenneth; Mouritsen, Jan (2005), Knowledge Management and Intellectual Capital, PALGRAVE MACMILLAN, New York

[22] Choo, Chun Wei; Bontis, Nick (2002), "The Strategic Management of Intellectual Capital and Organizational Knowledge", Oxford University Press, Inc., New York

[23]Hunter, Laurie. (2012), "Intellectual Capital: Accumulation and Appropriation", Melbourne Institute Working Paper, (22/02)

[24]Lopez Saez, Pedro; de Castro, Gregorio Martin; Navas Lopez, Jose Emilio; Delgado Verde, Miriam. (2010), "Intellectual Capital and Technological Innovation", Information Science Reference, United States

[25]Mondal, Amitava; Kumar Ghosh, Santanu (2012), "Intellectual capital and financial performance of Indian banks", Journal of Intellectual Capital, 13(4), pp. 515-530

[26] Nyman, John A. (2001), "The Demand for Insurance: Expected Utility Theory from a Gain Perspective", pp. 1-31.

[27] Osterville, J. Francois. (2013), "THE RELATIONSHIP BETWEEN INSURANCE AND ECONOMIC DEVELOPMENT: 85 EMPIRICAL PAPERS FOR A REVIEW OF THE LITERATURE", Risk Management and Insurance Review, 16)1(, pp. 71-122. 